Дупляк Т.П., к. е. н., дои.

Київський національний торговельно-економічний університет, м. Київ, Україна Google Scholar: https://scholar.google.com.ua/citations?user=XHQtgW4AAAAJ\&hl=uk

\title{
НАЦІОНАЛЬНІ ТРЕНДИ ОСВІТНЬОГО ТУРИЗМУ
}

Освітній туризм - це поїздки, під час яких турист поєднує відпочинок та навчання: відвідує заняття, здійснює екскурсії з метою розширення світогляду, задоволення цікавості та досягнення інших пізнавальних цілей. Відмінною рисою освітнього туризму є те, що він сприяє формуванню соціальної мобільності, професійної універсальності, навичок самоосвіти, стимулює інтелектуальний розвиток. Сфера освітнього туризму охоплює різні види навчання і освіти, які здійснюються поза постійним місцем проживання. Мотиви освітніх подорожей дуже різноманітні: від бажання з користю для саморозвитку провести вільний час, перебуваючи на відпочинку за межами звичного середовища, до прагнення реалізувати власні пізнавальні інтереси, набути нових знань та умінь, спеціально переміщуючись для цього у ті країни і регіони, де можна задовольнити ці потреби 3 максимальною ефективністю [1].

Головним інформаційним джерелом про вищу освіту в Україні для іноземців є Український державний центр міжнародної освіти Міністерства освіти і науки України. Центр є єдиною офіційною державною платформою, яка займається інформуванням щодо можливостей навчання. На офіційному сайті Українського державного центру міжнародної освіти (www.studyinukraine.gov.ua) абітурієнти можуть отримати загальну інформацію про навчальні програми, процедуру вступу та інші практичні поради. Окрім цього, абітурієнти можуть подавати он-лайн заявки на навчання до будь-якого закладу вищої освіти України через відповідний сайт. До послуг, які надаються Українським державним центром міжнародної освіти, входять: перевірка документів абітурієнта, допомога у виборі університету та навчальної програми, допомога з подачею документів до закладу вищої освіти, отримання запрошення на навчання, візова підтримка, організація зустрічі в аеропорту. 
Іноземці в Україні можуть здобувати вищу освіту українською, російською або англійською мовою, в залежності від пропонованих програм та рівня знання мови абітурієнтом. Іноземні студенти мають можливість навчатися у більш ніж 240 закладах вищої освіти і здобувати освіту за різними спеціальностями. У 2018 році заклади вищої освіти України прийняли 75605 студентів зі 154 країн світу, що на $12,3 \%$ більше ніж у попередньому році та на 40,9 \% більше ніж у 2011 році. Топ 10 країн за походженням іноземних студентів включає: Індію (19,78 \%), Марокко (9,77 \%), Азербайджан (8,24 \%), Туркменістан (6,66 \%), Нігерію (4,70\%), Сгипет (4,51\%), Туреччину $(4,30 \%)$, Китай $(3,60 \%)$, Ізраїль $(3,25 \%)$, Грузію $(3,17 \%)$. Понад $87 \%$ іноземних студентів припадає на основне навчання; 9,61\% - на мовну підготовку; $1,96 \%$ - на післядипломну освіту; $0,92 \%$ - на аспірантуру / докторантуру; $0,04 \%$ - на програми академічної мобільності. До закладів вищої освіти України 3 найбільшою кількістю іноземних студентів відносяться: Харківський національний медичний університет, Харківський національний університет імені В. Н. Каразіна, Одеський національний медичний університет, Запорізький державний медичний університет, Національний медичний університет імені О. О. Богомольця, Вінницький національний медичний університет імені М. І. Пирогова, Міжрегіональна Академія управління персоналом, Дніпропетровська медична академія Міністерства охорони здоров'я України [2].

Українським державним центром міжнародної освіти взято курс на набуття нової якості, серед яких головними є:

- забезпечення ефективного позиціонування України на міжнародному ринку освітніх послуг;

- активна популяризація української вищої освіти на цільових зарубіжних ринках;

- створення моделі набору іноземних абітурієнтів на навчання в Україні на принципах прозорості, відповідальності та комплексної профорієнтації;

- забезпечення моніторингу кількісних та якісних показників надання українськими навчальними закладами освітніх послуг іноземцям, підготовка статистики та прогнозів для прийняття Міністерством освіти і науки стратегічних рішень у цій галузі.

\section{Список бібліографічних посилань}

1. Ткачук Л.М. Освітній туризм у світі й в Україні // Науковий вісник Інституту міжнародних відносин НАУ. Серія: Економіка, право, 
політологія, туризм: Збірник наукових статей. Київ: Національний авіаційний університет, 2010. Вип. 2. С. 137-144.

2. Навчання в Україні: Український державний центр міжнародної освіти [Електронний ресурс] - Режим доступу : http://studyinukraine. gov.ua/uk/ 